\title{
A SOUTH AFRICAN ANNOTATION TO SHAME IN EZEKIEL 16
}

\author{
Marietjie Odendaal \\ Department of Old and New Testament \\ Stellenbosch University
}

\begin{abstract}
This article attempts to makes sense of the layering of different texts - by one another and by different reader responses. The juxtaposed texts are Ezekiel 16 and the TRC account by Antjie Krog. The different reader responses are created by both texts and are partly contributable to women's multiple identification, already mentioned. Ezekiel 16 is itself a layered text. Its central metaphor is "Jerusalem is a woman." The metaphor is worked out as a story of a married woman, shamed by her husband because of her infidelity. On another level, Ezekiel 16 is the story of the people of God's relationship with God in which God judges Judah-Jerusalem's disloyalty, but offers a prospect of restoration. Jerusalem the city is thus also a symbolic representation of population of the city and of Judah. Furthermore, one cannot neatly disentangle these levels.
\end{abstract}

\section{Introduction}

Ezekiel 16 had long troubled some of its readers with its explicit sexual and violent depictions. More recently, this text came under feminist scrutiny. ${ }^{1}$ Especially the function of shame in this chapter, as an essential part of restoration, caught feminist scholars' attention. My study of Ezekiel 16 coincided with an encounter with the Truth and Reconciliation Commission (TRC) through Antjie Krog's Country of my Skull. ${ }^{2}$ The result

1. Ezekiel 16, along with Ezekiel 23, presents a difficulty in its expression of the renewed relationship between God and Israel in terms of a husband-wife relationship which is renewed when the woman is shamed and knows her shame. The basic idea that this text by Ezekiel can be liberating at all has been challenged by feminist interpretations. The picture of the shamed woman can never be gospel, or "good news" for women. See, for example, Weems (1995), Gravett (1994), Darr (1992), Exum (1996), van Dijk Hemmes (1993), and even Dempsey, (1998: 75, 77). Such a view contradicts the assertion of other interpreters that these texts reveal God's grace. Compare Zimmerli (1979: 353), Swanepoel (1993: 87, 103), and Block (1997: 521). Feminist readings have convincingly alerted us to the fine print and implicit messages of these texts. Generally, and here in particular, Ezekiel does not portray God's graciousness and mercy.

2. My rendition of the TRC is limited and functional in terms of this paper. Since I am emphasizing biblical interpretation, I am accepting that the Krog version of the TRC hearings, though not comprehensive, is substantial enough to form the basis of a response to these hearings. Antjie Krog, a South African poet, has covered the TRC hearings as a journalist and consequently produced Country of My Skull (1998) about this experience. She starts with the establishment of the TRC and then presents testimonies before the TRC selectively, together with her own commentary. The testimonies include stories by victims during the apartheid era, with special attention to women's stories, as well as the testimonies of perpetrators of apartheidcrimes. The testimonies heard by the TRC have varied from individual presentation to presentations offered by institutions, such as political parties, church denominations, and government bodies. Throughout, Krog's own reaction as Afrikaans poet is presented. One of her initial reactions, especially relevant in light of Ezekiel 16, "no poetry should come forth from this. May my hand fall off if I write this" (ibid., 49) captures the dilemma of steering between remembering and naming on the one hand and profiting from others' pain on the other. One imagines that Ezekiel could be the result of a similar dilemma of choosing between fully naming and describing and the danger of perpetuating the violence. Krog's presentation of the TRC hearings, not a scientific or philosophical treatise, leaves a vivid impression of the past revealed in the TRC hearings and the present evoked by these revelations. 
was evocative enough to prompt further exploration of Ezekiel 16 and its resonance with the stories revealed during the TRC's work. Ezekiel's presentation of shame as appropriate human response became a possibly meaningful part of restoration. The encounter between Ezekiel's text and the TRC "text" was, however, ambiguous, since it was surrounded by the violence in both stories. Ambiguity lay, further, in the reader's identification with victims, aggressors, or both. ${ }^{3}$

In the article that follows, two responses to Ezekiel 16 take shape: one is resistance to the story of the shamed woman, along with feminist readers, the other is agreement with the guilt acknowledged by the shamed wife. The response to the TRC stories are also complex, expressing rejection of what women have been made to suffer and the acknowledgement of complicity in that suffering. Between these two texts there are resonance and recognition in the shaming of women and in the acknowledgement of guilt and complicity.

The article will proceed as follows. I continue with a reading of Ezekiel 16, where I first outline the contours of the context in which Ezekiel 16 appears (1). ${ }^{4}$ Then I will give a summary of the chapter (2). This summary will be interrupted by an excurses on shame, since I do not want to take the reading of shame for granted. Lastly, in part III, I will look at the convergence of the two concepts, women and shame, in Ezekiel 16 and the TRC stories as I evaluate the gains and limits of this reading.

\section{Reading Ezekiel 16}

\subsection{Ezekiel 16 in Context}

Ezekiel is a text of the exile, by its own explicit claim (Ezek 1:1-2), a text for an exiled group. It is, thus, a text for a socially marginalized and oppressed group trying to survive and make sense of the domination under which it finds itself. Ezekiel goes to great lengths to ascribe the proverbial last word to God, instead of the Babylonian empire. God's first words, coinciding with that of the empire, are "judgement" and "destruction." God's presence brings judgement in the forms of violence and exile. God's renewed presence, however, also promises a new beginning. God will forgive and re-enter relationships only after those who broke the relationship come to true knowledge of God and full acknowledgment of their guilt.

The first part of Ezekiel focuses on judgement, wrath, guilt, and punishment, while restoration makes only fleeting appearances. Yet, it recurs often enough to constitute a

3. Two levels of identification are possible: the woman reader can identify as victims or as perpetrators with women in stories. Denise Ackermann has spelled out the complexity of doing feminist theology for white South African women, who have been both oppressed and oppressors (Ackermann 1994: 198-99). This quandary is, however, not limited to South African women, but occurs in many different social settings. Though I identify with the women whose testimonies were told before the TRC, I also have to identify with the oppressor's side, because those who have confessed to apartheid-crimes claim to have acted in my name (Krog 1998: 97).

4. Chapter 16 should not be read in isolation from the texts surrounding it (see also Swanepoel 1993: 84 and Block 1997: 469, 734]). The context of Ezekiel 16 consists of the content of its surrounding chapters and actually the whole book, as well as the themes that run through the book to which chapter 16 contributes.

A basic division of Ezekiel is:

1-11, Announcement of Judgement

12-32, Guilt Defined

33-39, Announcement of Restoration

40-48, Peace Defined. 
theme. As the book progresses these appearances cumulate in effect. The book's final notions of peace or calm will secure the previous intimations. The variations on this theme lead to the book's ultimate vision of restoration.5 The presence of a shimmer of light in Ezekiel 11:17-20 or 6:8-10 is, therefore, not irrelevant for understanding Ezekiel 16. Although ignoring them leaves one unprepared for the book's end, one should also not read every promise in isolation, or the last vision into these presentiments of the finale.

Themes that appear in the texts surrounding chapter 16 are: presentations of Israel's story as the story of the insignificant made significant (Ezekiel 16, 17, and 23), and the story of a disappointing outcome to great promise (chapters 16, 19, 20, and 23). These themes support the pronouncement of severe judgment for Jerusalem-Israel in chapters 1618. Other themes are Israel's unfaithfulness to the relationship arranged by YHWH and attraction to other nations, as in chapters 16, 17, and 20 (Fishbane 1984: 140). Past and lineage are also employed thematically. The idea of lineage and the progress of generations are very striking in chapters 19 and 20 and colour our understanding of the oracle in chapter 16. Parentage, expressed in terms of parents, children, and generations, is a clue to understanding the past (Ezekiel 16, 17, 18, 19, 20, and 23). It is tied both to JerusalemIsrael's portrayal as a woman and Israel's place amongst the nations. Another feature of chapter 16, shared with Ezekiel 20 and 23, is its narration. The accusation of woman Jerusalem is expressed in terms of her story. Ezekiel 16, 20, and 23 represent three different "historical surveys" (Klein 1980:92), which tell the story of Israel or Jerusalem. Ezekiel's patterns and metaphors dominate: Israel's history never was one of a successful relationship between YHWH and Israel-Jerusalem and it all winds up in destruction. Ezekiel 16's participation in all these themes confirms that its context should not be disregarded.

Closer attention to two themes, Jerusalem-Israel's portrayal as a woman and its placement amongst the nations, is warranted. Women in Ezekiel not only function as women, but also metaphorically represent God's people. In chapters 12-24, various women appear, not only Jerusalem the wife and sex worker. The chapter 19 dirge very significantly tells the story of a lioness, a queen and mother, whose attempts to perpetuate greatness through her offspring fail utterly. She is a figure quite strikingly different from the mothers talked about in chapters 16 and 23. She plans for her sons, rather than abandon them and she fails only through them, not by the badness of her own actions. Galambush points out that, for example, the image of the pot (Ezekiel 22) is also female (Galambush 1992: 138). Women are mostly drawn as socially powerful. The possible exception may be the prophet's wife, who is the one non-metaphorical woman in these chapters (Ezekiel 24:1518). Women's (in)significance in Ezekiel is thereby nuanced.

Jerusalem is placed amongst the nations. Previous mention of the world beyond Israel was limited to the exilic setting (Ezekiel 1, for example), the nations as general audience (such as Ezekiel 5:15, 16:27), and mentions of exile (Ezekiel 12). Other nations serve to draw Israel's attention away from God. This power that the nations have is challenged in the oracles against the nations (Ezekiel 25-32,35) and, again, definitively threatened and broken in chapters 38-39. However, the pull is not only external, because it is already inherent in Israel-Jerusalem herself. The nations and being foreign are not only signs of the "other" for Jerusalem, they point to her own being and longings.

5. In Ezekiel 33 the destruction of Jerusalem is announced by a messenger. After that visions of restoration follow in which renewal begins to outweigh destruction (chapters 34, and 36-37). Chapters 38-39 envisions the final destruction of Israel's enemies and stumbling blocks to its wholeness and cleanness. The entry is then made into the new, established future of chapters $40-48$. 


\subsection{Ezekiel 16: A Summary}

Returning to Ezekiel 16, we will demonstrate the relevance of reading it in context and summarise its contents. ${ }^{6}$ Our summary will be influenced by points of contact between Ezekiel 16 and TRC stories. ${ }^{7}$

Ezekiel 16 is a long oracle in which the prophet is told to "make known to Jerusalem her abominations" (Ezekiel 16:2). The content of God's charges against Jerusalem comes after the assignment to the prophet. The accusation is shaped as the complaint of a husband against his wife, God being the husband and Jerusalem the wife.

First God sees abandoned Jerusalem and saves her life (Ezekiel 16:6-7). Then God arranges a relationship with her, establishing a marriage relationship. ${ }^{8}$ The steps of this arrangement have overtones of sexuality, cult, and politics. ${ }^{9}$ The images of woman, cult, and people are overlaid so that Jerusalem is not "every girl-child." then strikes out on her own (Ezekiel 16:15 ff.). Is this an assertion of independence and therefore deserving of our, the modern readers', whole-hearted approbation? Some interpreters suggest that we see here a woman taking responsibility for her own sexuality. ${ }^{11}$

6. Outline of Ezekiel 16

Introduction 1-2, Assignment to the prophet

Background, 3-14, Jerusalem is rejected by her family; Yahweh becomes the new family

Indictment, 15-34, Jerusalem rejects Yahweh

Punishment, 35-41b, Yahweh judges Jerusalem

Conclusion, 41b-45, Yahweh carries out judgement and becomes quiet

Consequences, 46-53, Jerusalem amongst her family: the unfavorable comparison

54-63, Jerusalem back with Yahweh: her true state (shame) and new relationship

Scholars often take the time to define the growth process of the whole chapter, e.g., Zimmerli (1979) on chapter 16. The idea that this oracle did not at first exist in its full sixty-three verses is then central to its interpretation. I am, however, going to focus on the full version of this oracle.

7. Resonance between Ezekiel and the TRC is strikingly created in women's exposure to violence and, especially, sexual violence. Interpretations based on women's experience are thus plainly relevant. "Because always, always in anger and frustration men use women's bodies as a terrain of struggle--as a battleground" (Krog 1998: 178). The terrorizing of women by men from the so-called security and police forces denied women's political power and reduced women to their presumed and ascribed sexual needs: "When they interrogated, they usually started by reducing your role as an activist. They weighed you according to their own concepts of womanhood ... And they said you are in custody because you are not the right kind of woman-- you are irresponsible, you are a whore, you are fat and ugly, or single and thirty and you are looking for a man ... And when whatever you stood for was reduced to prostitution, unpaid prostitution, the license for sexual abuse was created" (ibid., 179).

8. The use of the term "covenant" at this point hints at the overlap of different fields of reference in the use of the woman metaphor. The story of a newly married couple is used ambiguously to refer to religious and political situations. The term "covenant" itself has in the Old Testament multiple applications, that is, it can refer to marriage contracts, political agreements, and the bond between Israel and God. Mendenhall and Herion (1992: $1180,1194-1195)$ point out that marriage is a form of covenant and that banqueting can be part of the ratification of a covenant. See also Hugenberger (1994) on the covenantal aspects of marriage.

9. "See, your time was the time of love" (Ezekiel 16:8). Spreading the cloak also suggests a sexual relationship, see Ruth 3:9. The description of God's attention confers on Jerusalem sanctuary stature, since her decorations are the decorations and paraphernalia of the tabernacle (Galambush 1992: 95). She is given ruling status (Ezekiel 16:13) and "a name that goes out amongst the nations" (Ezekiel 16:14). The royalty that this girl is given is none other than a share in that of God, the king.

10. Likewise, not that all the husbands are that worthy, since Jerusalem's father is, after all, only an Amorite (Ezekiel 16:3, 45). Being man and husband does not place one on a level with God.

11. See Maier (1994), Seifert (1997) and Shields (1994). Such a reading would be based on a suspicion of male constructions of women's behavior and an understanding that neither law nor morality are gender- or interestneutral, and that the immorality noticed in someone (else) is always seen through "the eye of the beholder." As the story of all women who must always know dependence, this cannot be our story any longer. Yet, as a story of Israel who is before a choice of knowing dependence or acting independently and without restraints, it 
Yet, if the power ascribed to the woman is acknowledged, one must also reckon with the responsibility that accompanies that power.

The violence of which woman Jerusalem is accused is linked to memory. Her lack of memory leads, according to God's indictment, to all kinds of transgression, the chief of which is infidelity to her husband ("harlotry"12, Ezekiel 16:15-29). It also entails giving away to other nations what she has received from God. God accuses the woman of forgetfulness, "you did not remember the days of your youth" (Ezek 16:22, 43). ${ }^{13}$ While not remembering is a terrible failure, remembering rightly is the only hope (Ezekiel 16:60). That is when YHWH remembers. ${ }^{14}$

After giving a list of the woman's misdeeds, God interprets them: the woman is worse than any sex worker (Ezekiel 16:30-34). This causes great fury in God which bursts out against the woman in her punishment (Ezekiel 16:35-41). The punishment prescribed is particularly violent against the woman, the city and its people. And then God will be satisfied, "I will let rest my fury against you and take away my zeal from you; I will be quiet and will not become angry again" (Ezekiel 16:42, see also Ezekiel 5:13). ${ }^{15}$ As the story is told, the woman's gross violations therefore justifies and balances God's extreme anger.

Then, flowing out of a comparison between Jerusalem and her family, comes the demand for Jerusalem's shame. Before, the Philistine women were ashamed on behalf of Jerusalem (Ezekiel 16:27). The shame does not follow on her nakedness (Ezekiel 16:37), but is linked to her lineage. In contrast to the sisters' pride (Ezekiel 16:50), Jerusalem must know shame: "Yes you, carry your disgrace with which you interceded for your sisters; through your failures, which you achieved more abominably than they, you made them more righteous than you; Yes you, be ashamed and carry your disgrace with which you justified your sisters" (Ezekiel 16:52). In the comparison, furthermore, the indictment of Sodom is concrete: however well-fed, she did not move to support, to "strengthen the hand" of the poor and needy (Ezekiel 16:49). For Ezekiel the women (Jerusalem and Sodom) do not count amongst the poor and weak.

Thus Ezekiel 16 moves from rejection by lineage through creation of a new name by God. Initial family ties are severed with the rejection of the baby girl. God steps into the breach and into a familial-marriage relationship. This relationship is broken by the woman herself. Rejection of the name established by God returns the woman to her original lineage ("like mother like daughter," Ezekiel 16:44). The accusation against Jerusalem is revisited

sounds different. It denies not only women's independence but also the independence of God's people from God.

12. In the context of the legal regulation of women's bodies, sexuality is "concerned far more with property than with gender and sexual contact" (Matthews 1998: 97). Although words such as "harlot, concubine, wife, virgin, queen" now have fewer economic connotations, though often strong moral overtones, in the Bible these terms indicate economic and social relationships between households. "Promiscuity in the world of the Bible is not simply a lack of sexual discretion, but a symptom of the risks that a household is taking with its land and children. Husbands and fathers are responsible" (ibid., 98, 104).

13. Also elsewhere in Ezekiel lack of memory is an accusation: Ezekiel 20:43 ff, 36:31, and 6:8-10. The importance of memory in dealing with violence appears also in Krog's Country of My Skull (1998: 77), for example when a victim of torture has to face the lack of memory in his torturer: "That this experience, which has nearly destroyed his life, made not the slightest imprint on [the torturer's] memory" (ibid., 75).

14. Ultimately, the judgment for not-remembering in chapter 16 paves the way towards a salvation oracle built on these same concepts of remembrance and covenant (Baltzer 1986: 171).

15. When God becomes quiet with satisfaction it does not end the interaction between God and woman Jerusalem. It becomes the basis for a new arrangement. Some readers emphasize, based on their reading of Ezekiel 16:63, that in the new relationship the woman is quiet, but here God is actually the one who is "quiet" (Ezekiel $16: 41 b-42)$. 
and her shame expressed even more sharply in the comparison according to which Jerusalem surpasses her sisters in wrongdoing (Ezekiel 16:46-52), while their inferiority counts in their favor. ${ }^{16}$ The discussion of Jerusalem's shame (Ezekiel 16:53-58) leads to an announcement of a new arranged relationship with God (Ezekiel 16:59-60). Thus Jerusalem's shame and shaming have opened the way to something new. In the process of her punishment and re-acceptance by God her relationship with her family is established again: she is given her sisters as daughters (Ezekiel 16:61). Thus lineage, implying race and class, forms a frame for the indictment and punishment of the woman. As we have seen, it is also a link to the surrounding chapters.

\subsection{Excursus: Shame in Ezekiel 16}

Shame in Ezekiel 16 is a woman's shame. Yet references to male shame appear elsewhere in Ezekiel. The exile itself is a shaming event (Ezekiel 12:11-13). Other instances of shaming are: dishonor in death (Ezekiel 28-32, concerning Tyre and Egypt), and defeat and annihilation (the lion cubs in Ezekiel 19). Shame appears at various points as the consequence of God's judgement, but also as part of restoration, alongside memory (Ezekiel 20, for example). The whole Israel bears shame in Ezekiel as part of its restoration (Ezekiel 36:32; 39:26; 43:10-11 ${ }^{17}$ ). Furthermore, in Ezekiel 16, especially in Ezekiel 16:6063 , shaming appears in the context of a specific story as a prominent motif in that story. ${ }^{18}$ Shame is also related to the following topics: lineage, the public, evaluation, and covenant (Brandes 1987: 128). ${ }^{19}$ The shame of the woman, so graphically and disturbingly described, is related to misdeeds against God, to guilt. ${ }^{20} \mathrm{An}$ arranged relationship leads to remembrance and shame (Ezekiel 16:60-61, 62-63), but that in turn leads to forgiveness and restoration, so that ill fame is ended. Shame does not represent a lasting state nor does it define a person totally (Brandes 1987 and Wikan 1984). Wikan shows that though a woman might be known as unfaithful to her husband and therefore "shamed," in different Mediterranean societies this will not comprise a final value judgement of the woman.

Shame as the guide to good behavior in a woman, as it often functions in the Mediterranean world, is more helpful for understanding the ending of Ezekiel 16 than a notion that the woman is left with no self-esteem and totally silenced before God (Klein 1995: 151). In the latter case, reconciliation after severe punishment might well have no merit in light of the picture of Jerusalem as "confounded and struck dumb with shame in the face of her Lord's forgiveness" (Darr 1992: 106-7). In psychology the discussion of

16. The fact that Sodom is called Jerusalem's sister undermines a construction of ethnicism in this oracle. It seems to suggest, rather, that Jerusalem-Israel does not differ from the surrounding nations in any intrinsic, blooddefined way.

17. A related term is used in Ezekiel 6:9, 20:43, and 36:31. In all these references to shame or disgust felt by Israel or Jerusalem at its restoration, memory triggers Israel's response and is essential to the process of restoration.

18. In 16:63 shame (to be ashamed) is linked to the arrangement of a relationship and with the knowledge formula (Klopfenstein 1972: 73).

19. Shame and shaming are likely to be public, since they are "means of social modification." When these measures fail, others can be imposed (Matthews 1998: 98). Covenant is set up, through ritual, already in Ezekiel 16:8-14. Compare Olyan (1996: 210). Olyan's article, which analyses the ubiquity of shaming in covenant contexts, points away from the idea that the woman is shamed "as woman" more than as "partner" or "client."

20. I am not upholding an opposition between shame and guilt, either in terms of culture (Peristiany and PittRivers 1992: 6-7) or terminologically. Klopfenstein's study of shame-terms in the Old Testament leads him to conclude that a real opposition, light/heavy (qal/kabod), exists only with these specific roots. Therefore, one cannot wholly link the complex shame/disgrace to its supposed opposite, "honor." Furthermore, shame is linked to guilt in the Old Testament (Klopfenstein 1972: 208). 
shame focuses on internalized and personal feelings or experiences. No external referent or underlying wrong-doing is acknowledged when the shame people feel is analyzed (Morrison 1996: 107). ${ }^{21}$ Those who say "no" to shame for the women in Ezekiel 16 echo discussions of shame in psychology, where shame is also seen as a burden from which individuals must be freed in order to be fulfilled. Since the shame is patriarchal, one must be liberated from it.

Women's guilt and shame in Ezekiel 16 relates shame to putting an end to guilt. Contemporary readings of these texts which free women from the shame they undergo at the hands of Ezekiel, at the same time free them from guilt. The liberating moment is exhilarating in light of women's real experiences of systemic gender oppression and the concomitant equation of womanhood with a state of shame. This same liberating moment, however, deprives women of their share in a humanity that is responsible and, therefore, in some instances guilty of failure to carry out that responsibility. I, therefore, propose that Ezekiel 16 offers a chance to deal with guilt, which leads to shame when it is faced. However, the shame condition is neither the goal nor the final state. One cannot conclude from this that Ezekiel's texts about shamed women are a "message," some kind of imperative, to people, whether men or women. ${ }^{22}$ The alternative I seek is to continue rejecting the notion that shame is inherent to women, but yet to hold on to the possible guilt and shame of people, including women. I thus want to retain the possibility that Ezekiel 16 is not only a woman unfriendly metaphor. One aspect of this text can in some circumstances, though clearly not everywhere or everyday, serve wholeness. Furthermore, this aspect is not abstracted from the metaphoric story, but arises from it.

Now, returning to the summary, Ezekiel 16 ends with the reassuring threat, "and you will know that I am YHWH" (Ezekiel 16:62). Since knowledge of God is gained in covenant, breach of covenant is dismissal of that knowledge. Remembering is regaining knowledge and the reestablishment of relationship. For the woman, remembrance and shame go together, but carrying her shame means that she is no longer the byword she was (Ezekiel 16:63). ${ }^{23}$ The new relationship is based on covering ${ }^{24}$ and not on the perpetuating

21. Morrison (1996), for example, argues that shame is a human condition that must be overcome to gain health. Susan Miller includes, however, another side to shame, that it can function as a survival mechanism (Miller 1996: 152).

22. The correspondence between Ezekiel 16 and TRC stories suggests a grave risk that torturers might identify with God and so consider themselves, again or doubly, justified. One must also remember that this is exactly the accusation levelled against Ezekiel 16 (see, for instance, Exum 1996: 103, and Weems 1995: 34). Is the risk in this text not so great that it can only be rejected? On the other hand, is the gain in exonerating the woman in Ezekiel 16 purely that of saving the "poor woman" and all women or is there also the investment that is served by writing away the guilt of a woman, a rich and powerful one?

23. This verse is commonly read as "so that you will remember and be ashamed and you will not again open your mouth because of your disgrace, when I forgive you for all you did." It is not really convincing to interpret the literal Hebrew, "and there will not again be for you an opening of the mouth because of your disgrace," as "and you will not again open your mouth ..." We have support from Block (1997: 519) for our translation but even more from the text itself. The text's other references to rumour and byword and to what others say about Jerusalem because of her disgrace (Ezekiel 16:14, 27,44) make it more plausible to read here, that such rumour will now end. The significance of this verse lies in its implications for shame: is the effect of feeling shame that one is struck dumb? We argue, to the contrary, that the effect of shame is that one's proper relation to and position in society is restored, that, therefore, one is no longer a rumour or byword.

24. YHWH says, "when I cover you" ( $k p r, 16: 63)$. This Hebrew root, in the Pi'el is often translated "to make atonement," as also in Ezekiel 43: 20, 26, 45:15, 17, 20. In those chapters it is the temple, the whole people of Israel, and the altar that must be "covered" by sacrifices. It is striking that Ezekiel, with this expression of God's promised action, anticipates the detailed description of the restored Jerusalem temple and its cult, starting in Ezekiel 40. 
of her past, either in word or deed. Jerusalem's shame is thus a condition for God's hospitality or openness to a new arrangement.

Reading Ezekiel 16 while keeping the rest of the book in mind frees us from the urge to see the last verses as an incredible climax. Since chapter 16 is still part of Ezekiel's elaboration of Israel-Jerusalem's guilt and resulting punishment, I want to read, with these chapters, the last verses as an indication of direction. It is only in chapters $40-48$ where restoration is full-blown, while as yet in chapter 16 it is only a small cloud, maybe the size of a hand.

The points of contact between this story and the TRC stories are multiple: the brutal violence in both, the need for memory, and the battles fought on women's bodies. In Ezekiel 16 both the accusations against the woman (what she does) and her punishment (what is done to her) are similar to what the aggressors in the TRC stories do. The option to bring together the "be ashamed" of Ezekiel 16's last verses and "we are deeply ashamed and gripped with remorse. But hear us, we are from here" (Krog 1998: 99) in response to the TRC hearings thus remains.

\section{Evaluation: Gains and Limits}

With this paper I wanted to open up the options for reading Ezekiel 16, with accountability to feminist concerns. I asserted that hermeneutically "tearing out" the pages on which these texts are written would not be solely liberating. My reading tried to reflect the entanglement, the complex and even confusing interplay of images from this text and from other "texts," namely, Krog's descriptions of TRC hearings and analyses of women's experience. Would a concern over the violent reaction to the woman's independent ways totally compromise the outcome, namely reconciliation between the partners? Had God's return to an arranged relationship with the woman finally been exposed as completing and condoning the violating of the woman?

I have, for instance, wondered whether I should have withheld my response to these perceived convergences and sought for other, less offensive Old Testament texts which might bring about the same effects. Is it just the way in which Ezekiel 16 portrays guilt which is unacceptable, or would Psalm 51, for example also not apply to women? Alternatively, is there a "better" text to use in response to the reality of South Africa's past? Apart from the appropriateness of this "reading event" in terms of time and my personal experience and situation, I think the texts themselves need not be deleted because they are so fraught with tension, and because they arise from a larger narrative, and because they are complex.

Feminist thinking places heavy emphasis on naming correctly. Seifert, for example, objects strenuously to what she calls "false naming," that is, naming from male prejudiced points of view, in Ezekiel 16 (Seifert 1997: 264, 269, 271). However, the possibility still remains that Ezekiel is naming correctly on another level when it describes violence such as the woman's violence against her children in (Ezekiel 16:20-21). Do Ezekiel's oracles "call for violence" or can one understand Ezekiel as an extended effort to explain and give expression to the violent events of exile and temple destruction? Ezekiel then rather functions as a kind of testimony to these events of destruction.

The warning sounds constantly, that men might want to claim for themselves a satisfying indentification with God against the woman's wrong-doing. The resistance to the images in the text, which I have learnt from these readings, is related to my resistance to the stories from the TRC. The awareness that women's experiences of violence are often overlooked and dismissed, as well as exposure to such stories from many different contexts have intensified the hurt and shock conveyed by TRC stories of such violence. Allowing 
onself to hear these stories seems to invite anger and sadness and creates a resistance to the causes and actors which made them happen. Out of this gravelly resistance has grown an intimation and, finally, a conviction of complicity and of renewal. While I want to take seriously the possibility that I and other women can fail and thereby be guilty, I also want to hold on to the possibility that such failure and guilt does not signal an end, but a stage in a process. This process I understand to be one of facing realities and of truthful selfevaluation. 


\section{BIBLIOGRAPHY}

Ackermann, DM 1994. Faith and Feminism: Women Doing Theology, in JW de Gruchy and C Villa-Vicencio (eds) Doing Theology in Context: South African Perspectives, 197-211. Cape Town \& Johannesburg/ Maryknoll: David Philip/ Orbis.

Baltzer, D 1986. Literarkritische und literarhistorische Anmerkungen zur Heilsprophetie im Ezechiel-buch, in Johan Lust (ed) Ezekiel and his Book: Textual and Literary Criticism and their Interrelation, 166-81. Leuven: Leuven University Press.

Block, DI 1997. The Book of Ezekiel: Chapters 1-24. Grand Rapids, Cambridge: WB Eerdmans.

Brandes, S 1987. Reflections on Honor and Shame in the Mediterranean, in DD Gilmore (ed) Honor and Shame and the Unity of the Mediterranean, 121-134. Washington: American Anthropological Association.

Darr, KP 1992. Ezekiel's Justifications of God: Teaching Troubling Texts. JSOT 55: 97117.

Dempsey, CJ 1998. The 'Whore' of Ezekiel 16: The Impact and Ramifications of GenderSpecific Metaphors in Light of Biblical Law and Divine Judgment, in VH Matthews, BM Levinson, and T Frymer-Kensky (eds) Gender and Law in the Hebrew Bible and the Ancient Near East, . JSOT Supplement Series 262. Sheffield: Sheffield Academic Press.

Exum, JC 1996. Plotted, Shot, and Painted: Cultural Representations of Biblical Women. JSOT Supplement Series 215, DJA Clines and PR Davies (eds). Sheffield: Sheffield Academic Press.

Fishbane, M 1984. Sin and Judgment in the Prophecies of Ezekiel. Interpretation 38: 131-50.

Galambush, J 1992. Jerusalem in the Book of Ezekiel: The City as Yahweh's Wife. Atlanta: Scholars Press.

Gravett, S 1994. That All Women May be Warned: Reading the Sexual and Ethnic Violence in Ezekiel 16 and 23. Ph.D. Dissertation. Duke University.

Hugenberger, GP 1994. Marriage as a Covenant: A Study of Biblical Law and Ethics Governing Marriage Developed from the Perspective of Malachi. Leiden, New York, Cologne: EJ Brill.

Klein, LR 1995. Honor and Shame in Esther, in A Brenner (ed) A Feminist companion to Esther, Judith, and Susanna, 149-175. Sheffield: Sheffield Academic Press.

Klein, RW 1980. Ezekiel: The Prophet and his Message. Columbia: University of Chicago Press.

Klopfenstein, MA 1972. Scham und Schande nach dem Alten Testament. Eine begriffsgeschichtliche Untersuchung zu den hebräischen Wurzeln bos, klm und hpr. Abhandlungen zur Theologie des Alten und Neuen Testaments 62. Zürich: Theologischer Verlag.

Krog, A 1998. Country of My Skull. Johannesburg: Random House.

Maier, C 1994. Jerusalem als Ehebrecherin in Ezechiel 16: Zur Verwendung und Funktion einer biblischen Metaphor, in contr. Hedwig Jahnow et al Feministische Hermeneutik und Erstes Testament: Analysen und Interpretationen, 85-105. Stuttgart, Berlin, Cologne: W. Kohlhammer.

Matthews, VH 1998. Honor and Shame in Gender-Related Legal Situations in the Hebrew Bible, in VH Matthews, BM Levinson, and T Frymer-Kensky (eds) Gender and Law in the Hebrew Bible and the Ancient Near East, 97-112. JSOT Supplement Series 262. Sheffield: Sheffield Academic Press. 
Mendenhall GE and GA Herion 1992. Covenant, in DN Freedman (ed) Anchor Bible Dictionary vol 1, 1179-1202. New York: Doubleday.

Miller, SB 1996. Shame in Context. Hillsdale, NJ and London: The Analytic Press.

Morrison, AP 1996. The Culture of Shame. New York: Ballantine Books.

Olyan, SM 1996. Honor, Shame, and Covenant Relations in Ancient Israel and its Environment. JBL 115/2: 201-218.

Peristiany, JG and J Pitt-Rivers 1992. Introduction, in JG Peristiany and J Pitt-Rivers (eds) Honor and Grace in Anthropology, 1-17. Cambridge: Cambridge University Press.

Seifert, E 1997. Tochter und Vater im Alten Testament: Eine ideologiekritische Untersuchung zur Verfügungsgewalt von Vätern über ihre Töchter. Neukirchener Theologische Dissertationen und Habilitationen 9. Neukirchen-Vluyn: Neukirchener Verlag.

Shields. M 1994. Ezekiel 16: Body Rhetoric and Gender. SBL Paper, Typewritten Manuscript, Chicago.

Swanepoel, M G 1993. Ezekiel 16: Abandoned Child, Bride Adorned or Unfaithful Wife, in PR Davies and DJA Clines (eds) Among the Prophets, 84-104. Sheffield: Sheffield Academic Press.

Van Dijk-Hemmes, F 1993. The Metaphorization of Woman in Prophetic Speech: An Analysis of Ezekiel XXIII. VT 43/2: 162-170.

Weems, RJ 1995. Battered Love: Marriage, Sex, and Violence in the Hebrew Prophets. Overtures to Biblical Theology. Minneapolis: Fortress Press.

Wikan, U 1984. Shame and Honour: A Contestable Pair. Man 19: 635-52.

Zimmerli, W 1979. Ezekiel 1. A Commentary on the Book of the Prophet Ezekiel, Chapters 1-24, RE Clements (transl). FM Cross et al (eds) Hermeneia - A Critical and Historical Commentary on the Bible. Philadelphia: Fortress Press, 1979. 